$\begin{array}{ll} & \text { Etnográfica } \\ \text { etnográfica } & \text { Revista do Centro em Rede de Investigação em }\end{array}$

Antropologia

vol. 20 (2) | 2016

Vol. $20(2)$

\title{
La fragilidad de las especies: tensiones entre biólogos y pescadores artesanales en torno a la conservación marina
}

Fragility of species: tensions between biologists and artisanal fishermen about marine conservation

\section{María Carman y Victoria González Carman}

\section{(2) OpenEdition}

\section{Journals}

\section{Edición electrónica}

URL: https://journals.openedition.org/etnografica/4333

DOI: 10.4000/etnografica.4333

ISSN: 2182-2891

\section{Editor}

Centro em Rede de Investigação em Antropologia

Edición impresa

Fecha de publicación: 1 junio 2016

Paginación: 411-438

ISSN: 0873-6561

Referencia electrónica

María Carman y Victoria González Carman, «La fragilidad de las especies: tensiones entre biólogos y pescadores artesanales en torno a la conservación marina», Etnográfica [En línea], vol. 20 (2) | 2016, Publicado el 29 junio 2016, consultado el 09 febrero 2022. URL: http://journals.openedition.org/ etnografica/4333 ; DOI: https://doi.org/10.4000/etnografica.4333

\section{(c) (7) \&}

Etnográfica is licensed under a Creative Commons Attribution-NonCommercial 4.0 International License. 


\section{La fragilidad de las especies:} tensiones entre biólogos y pescadores artesanales en torno a la conservación marina

\section{María Carman y Victoria González Carman}

Este artículo analiza en forma interdisciplinaria las relaciones humano-animal de un grupo de pescadores artesanales de Argentina, cuyo oficio los lleva a capturar incidentalmente mamíferos y reptiles marinos amenazados. Abordaremos la interacción entre esta comunidad y un grupo de biólogos que busca la conservación de esas especies. Nuestra hipótesis es que las relaciones humano-animal comprendidas en la práctica de pesca artesanal de esta comunidad pueden ser explicadas a partir de una yuxtaposición de los tres paradigmas definidos por Pálsson (2001): el orientalista, el paternalista y el comunalista. Si bien los pescadores clasifican a las especies animales en torno a su posibilidad de ser explotadas como recurso, eventualmente negocian con los biólogos la protección de alguna de estas, reinventándose como conservacionistas estratégicos. La convivencia de los primeros dos paradigmas no opaca además el tácito comunalismo que impregna el mundo del trabajo y de la vida de los pescadores.

PALABRAS-CLAVE: pesca, conservación, relaciones humano-animal, interdisciplina, tortugas marinas, delfines.

Fragility of species: tensions between biologists and artisanal fishermen about marine conservation - This article analyzes, from an interdisciplinary perspective, the complexity of human-animal relations of fishers from Argentina. In their daily activities, they incidentally capture threatened marine reptiles and mammals. Our purpose is also to address the interaction between this fishing community and a group of biologists that seek to protect these species. Our hypothesis is that the human-animal relations in the practice of artisanal fishing may be explained from an alternation or juxtaposition of the three paradigms defined by Pálsson (2001): orientalism, paternalism and communalism. While fishers classify the species around their possibility of being exploited or not as resources, they negotiate with the biologists the protection of any of them. In this sense, they reinvent themselves as strategic conservationists. Finally, the coexistence of the first two paradigms does not preclude the tacit communalism that permeates the world of work and life of this fishing community.

KEYWORDS: fishing, conservation, human-animal relations, interdisciplinary, sea turtles, dolphins.

CARMAN, María (mariacarman1971@gmail.com) - Universidad de Buenos Aires, Consejo Nacional de Investigaciones Científicas y Técnicas, Instituto de Investigaciones "Gino Germani”, Argentina. 
GONZÁLEZ CARMAN, Victoria (vgcarman@gmail.com) - Instituto de Investigaciones Marinas y Costeras, Consejo Nacional de Investigaciones Científicas y Técnicas, Instituto Nacional de Investigación y Desarrollo Pesquero AquaMarina, Argentina.

"Lo que sé sobre las tortugas está bien adentro de mi corazón, las tortugas están dentro de mi vida, y lo que te digo sobre las tortugas es verdad, y yo sé que es verdad" (testimonio de Kavusu, nativo de las Islas Salomón, en Hviding 2001: 205).

\section{INTRODUCCIÓN}

Este trabajo resume una experiencia interdisciplinaria entre una bióloga y una antropóloga en el estudio de una comunidad de pescadores artesanales de San Clemente del Tuyú, un poblado ubicado en la provincia de Buenos Aires, Argentina (figuras 1 y 2). ${ }^{1}$ En su tarea diaria, los pescadores interactúan con especies de delfines y tortugas marinas amenazadas que habitan las aguas de la Bahía Samborombón. En el arte de pesca ${ }^{2}$ utilizado por los pescadores - la red de enmalle - los animales quedan atrapados y, frecuentemente, esta captura de naturaleza incidental puede desembocar en su muerte. ${ }^{3}$

Si bien una de nosotras contaba con una modesta trayectoria de interacción con los pescadores en el estudio de la problemática de la captura incidental de delfines y tortugas marinas, nuevas lecturas e interrogantes la llevaron a torcer el rumbo de su experiencia práctica. Así es que decide convocar a una colega antropóloga no solo para continuar la investigación en forma conjunta, sino también para problematizar el confortable campo de la biología que hasta entonces había cobijado sus preocupaciones. La experiencia interdisciplinaria resume, pues, casi diez años de relación de una de nosotras con los pescadores artesanales, sumados a casi tres años de trabajo etnográfico en equipo. ${ }^{4}$

l Esta investigación se desarrolló en el marco del proyecto "Understanding the human dimension of bycatch of large marine vertebrates in a small-scale fishery of Argentina" que contó con el apoyo del Global Fellow Mini Grant Award (Duke Univeristy Marine Laboratory, USA), Ideawild y el MAB Young Scientists Award edición 2015 de UNESCO. Esta es la contribución INIDEP no. 1977.

2 La denominación genérica "arte de pesca" hace referencia a los aparejos, artefactos e instrumentos que los pescadores utilizan en el proceso material de extracción (Mateo 2003).

3 El término técnico que se aplica a esta situación es captura incidental, y se define como la porción de la captura que es descartada al mar muerta o seriamente lastimada ya sea porque posee poco valor económico, o bien porque su retención está prohibida por ley (Hall 1996).

4 Durante el período 2013-2014 entrevistamos un total de 17 pescadores, individualmente o en grupos, dependiendo de las circunstancias. Cuando visitamos a los pescadores en sus hogares, [continua] 


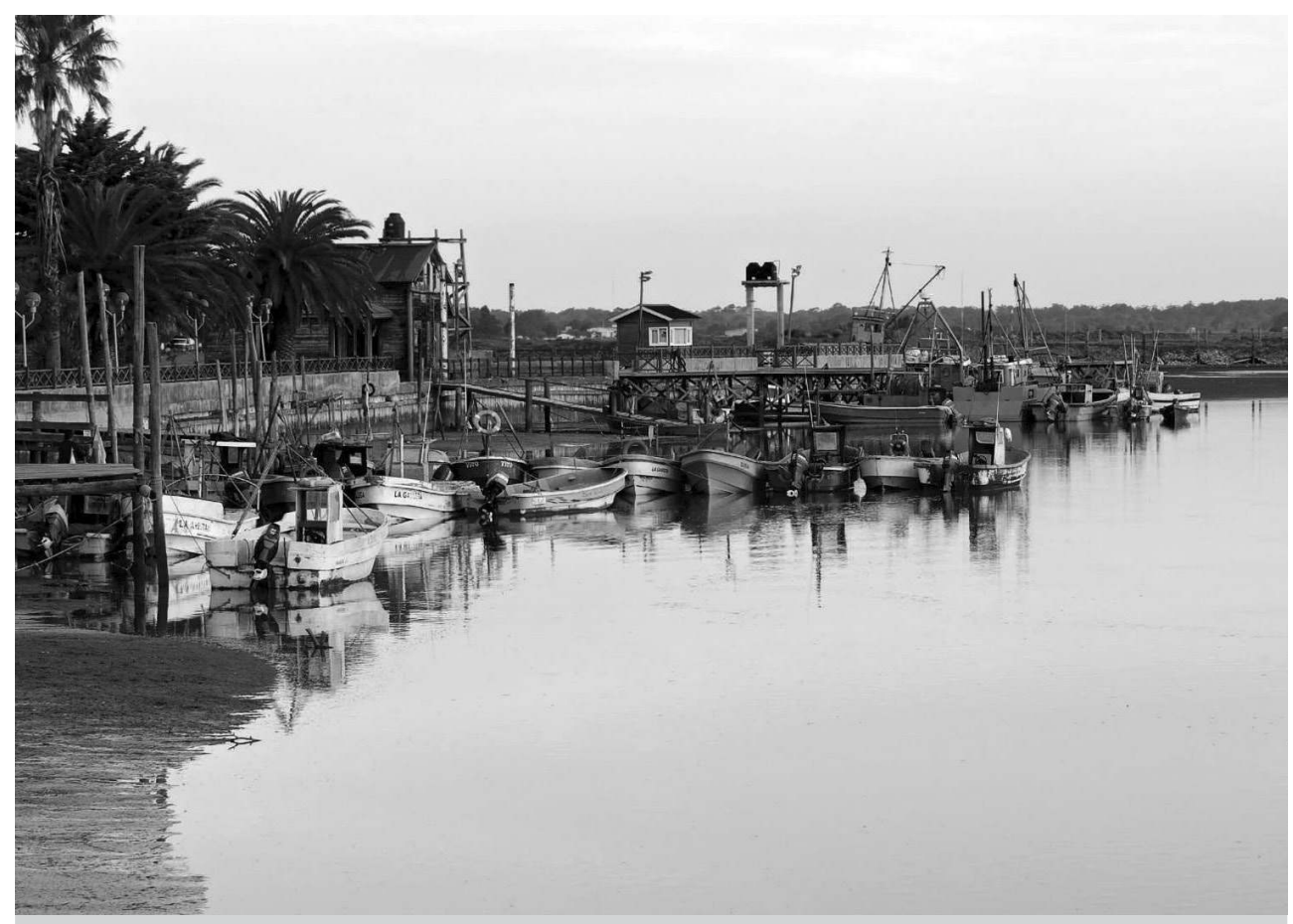

Figura 1 - Puerto de San Clemente del Tuyú, Argentina. Foto: Gabriel Battaglia.

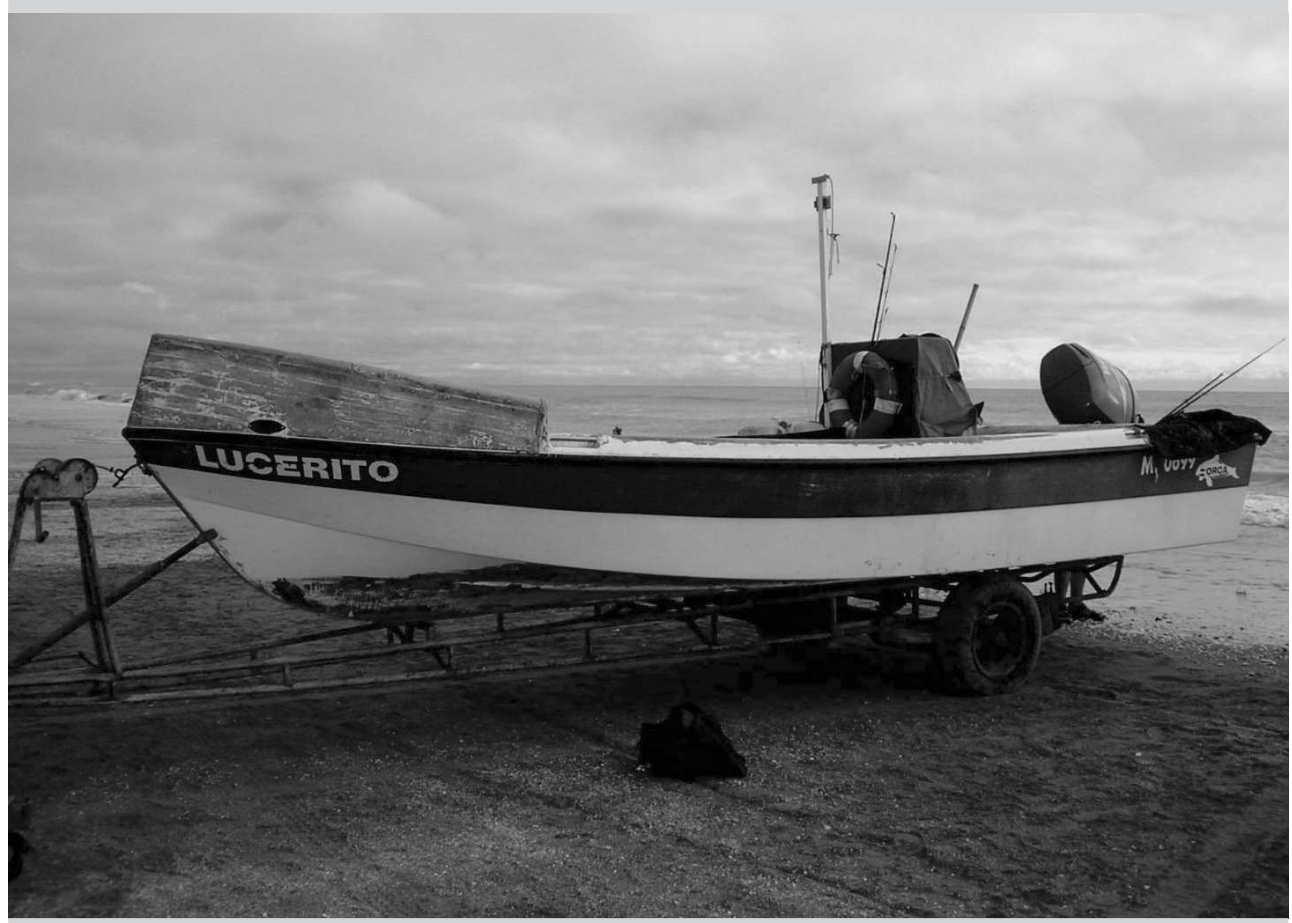

Figura 2 - Lancha de pesca artesanal. Foto: AquaMarina. 
En el presente artículo abordaremos la relación que se establece entre los pescadores artesanales y algunas especies animales con las cuales entran en contacto en su práctica de trabajo: peces como la corvina rubia (Micropogonias furnieri), la pescadilla de red (Cynoscion guatucupa) o la lisa (Mugil platanus), y también delfines, tortugas y lobos marinos. Estas últimas especies, sin importancia comercial, son consideradas animales carismáticos. ${ }^{5}$ En este grupo se encuentran principalmente el delfín franciscana (Pontoporia blainvillei) y tres especies de tortugas marinas (Chelonia mydas, Caretta caretta, Dermochelys coriacea) considerados en riesgo de extinción (figura 3). ${ }^{6}$ La fragilidad de estas especies genera gran preocupación en una serie de expertos dedicados a la conservación de la biodiversidad, mayormente biólogos trabajando en organismos del Estado u organizaciones no gubernamentales (ONG).

Nuestra hipótesis es que las relaciones humano-animal comprendidas en la práctica de pesca artesanal de esta comunidad pueden ser explicadas a partir de una alternancia o yuxtaposición de los tres paradigmas definidos por Pálsson (2001): el orientalista, el paternalista y el comunalista.

El orientalismo abarca todas aquellas relaciones de exploración, conquista y explotación del medio ambiente impulsadas por el hombre, propias del imperialismo occidental. El término orientalismo se refiere a la concepción que dominó en las ciencias y las humanidades europeas desde el final del siglo XVIII y tuvo su consagración en el siglo XIX. Esta concepción se asienta en la distinción total entre "nosotros", los occidentales, y "ellos", los orientales. Occidente es racional, desarrollado, superior, mientras que Oriente es inferior, temible y tiene que ser controlado por Occidente (mediante la guerra, ocupación, investigación científica, etc.) (Santos 2001). En el marco de este paradigma predomina una reciprocidad negativa en las relaciones humano/no humano, en las que la naturaleza - desbordante y problemática - debe ser sistematizada

[continuación] tuvimos la posibilidad de hablar con ellos en privado. Cuando los encontrábamos en el puerto o las pescaderías, entrevistábamos a más de un pescador a la vez. Algunos de ellos fueron entrevistados en varias ocasiones en viajes sucesivos, lo que nos permitió profundizar ciertas preguntas. 5 Se entiende por animales carismáticos a aquellos que despiertan un vivo interés en la sociedad, y cuyas representaciones icónicas suelen combinar singularidades físicas y espirituales. Esas imágenes forman parte de campañas y logos de organizaciones conservacionistas que, sintonizando con los sentimientos de responsabilidad y compasión que estos animales generan en el público, los utilizan como "especies bandera" para proteger especies menos populares, así como los hábitats de los cuales dependen.

6 El estado de conservación de estas especies es determinado por la Unión Internacional para la Conservación de la Naturaleza (IUNC, por sus siglas en inglés). La IUCN convoca a 8000 científicos y expertos de más de 180 países para contribuir anualmente al diagnóstico del estado de conservación de unas 50.000 especies. Este diagnóstico, denominado Lista Roja de Especies Amenazadas, es una base de datos que abarca tanto especies recientemente extinguidas como otras de bajo riesgo actual de extinción. Tres de las categorías con las que se clasifican estas especies - en peligro crítico, en peligro y vulnerable - conforman el grupo de las especies amenazadas de extinción. 


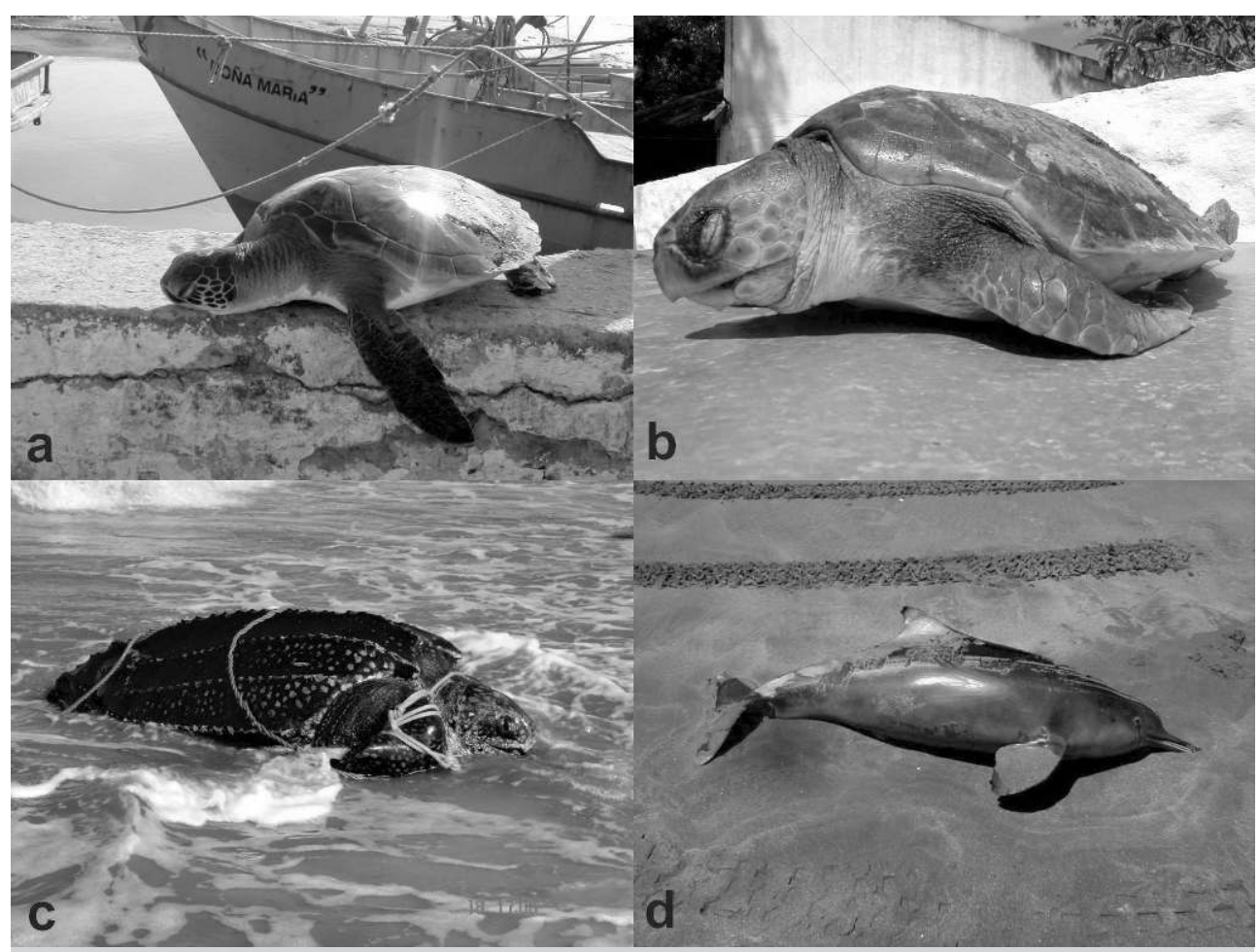

Figura 3 - Especies marinas amenazadas. a) tortuga verde (Chelonia mydas), b) tortuga cabezona (Caretta caretta), c) tortuga laúd (Dermochelys coriacea), y d) delfín franciscana (Pontoporia blainvillei). Fotos: AquaMarina.

y domesticada (Pálsson 2001: 87). ${ }^{7}$ Transformada en un recurso natural, la naturaleza queda a merced de los humanos y no admite otra lógica que la de ser explotada hasta la extenuación (Santos 2001). Las consecuencias de esta sostenida depredación del medio ambiente se evidencian en múltiples problemáticas que todos conocemos como la degradación del medio ambiente y la continua extinción de especies.

Por su parte, el paternalismo supone una relación de protección de la naturaleza. Este paradigma implica una reciprocidad equilibrada, en la cual los humanos tienen una responsabilidad particular sobre los animales y aquellos segmentos de la humanidad considerados "dentro de la naturaleza" como, por ejemplo, los pueblos indígenas. El paternalismo es claramente perceptible en

$7 \quad$ Esta postura puede encontrarse en los primeros conquistadores de América, quienes percibían a la naturaleza del "nuevo continente" como hostil y peligrosa. En la época de la colonia, ciertos recursos fueron considerados inagotables y esto justificó su intensa explotación. En el río Paraná, por ejemplo, se pescaban más sábalos de lo que se consumían: una vez elegidos los de mayor tamaño, se dejaba morir al resto (Brailovsky y Foguelman 2013). 
los discursos que, preocupados por adoptar medidas de protección y reglamentos estrictos en el manejo de los recursos naturales, alertan sobre las "consecuencias ecológicas de las actividades humanas" (Pálsson 2001: 89-90). ${ }^{8}$

Pese a sus diferencias, el paradigma orientalista y el paternalista comparten la visión de que los humanos son los amos de la naturaleza, a la vez que perpetúan la dicotomía naturaleza-sociedad característica de nuestra cultura occidental. El comunalismo, en cambio, rechaza esta fractura. Bajo este paradigma, los humanos establecen con los animales relaciones de una estrecha cooperación. Los animales son tratados como iguales y considerados "personas" que pertenecen a la sociedad que contiene a todos los seres. Existe aquí una reciprocidad generalizada que suele encontrarse, por ejemplo, en las sociedades de cazadores y recolectores (Pálsson 2001: 89-90).9

En concordancia con los dos primeros paradigmas - el orientalista y el paternalista -, observamos que si bien los pescadores de San Clemente clasifican a las especies animales en torno a su posibilidad de ser explotadas o no en tanto recurso, eventualmente pueden negociar con otros actores - tales como "los biólogos" 10 - la protección de alguna de estas. En tal sentido, algunos pescadores de San Clemente se reinventan a sí mismos como "conservacionistas estratégicos" en relación a aquellos animales prestigiosos, cuyo potencial simbólico se extiende a ellos. Adicionalmente, hemos de argüir que los pescadores de San Clemente sostienen una relación de intimidad con el mar y sus habitantes que bien puede ser definida como un comunalismo implícito. Esta cercanía es fruto de incontables horas de trabajo en el mar, en las cuales se produce un renovado intercambio entre humanos y animales.

En este artículo hemos de abordar los principales hitos de las interacciones entre pescadores y biólogos respecto de la conservación de especies en riesgo, para luego profundizar en nuestra hipótesis de la yuxtaposición de los tres paradigmas mencionados - orientalista, paternalista y comunalista - en las praxis y representaciones de los pescadores.

8 Volvamos al ejemplo anterior: si bien en la época de la colonia ciertos recursos se dilapidaron, otros comenzaron a ser percibidos como escasos y necesarios de protección. La vicuña, por caso, era perseguida por la calidad de su lana y su esquila podía realizarse de modo más rápido y económico si se la sacrificaba. La posible reducción de sus poblaciones y el eventual encarecimiento de la lana condujo a prohibir su caza y restringir la esquila para evitar la aniquilación de la especie (Brailovsky y Foguelman 2013).

9 En el caso de los inuits trabajado por Ingold (2000: 67), los animales se presentan intencionalmente al cazador que ha de matarlos para su consumo. Si los hombres les causan sufrimiento o cazan más de lo necesario, los animales no vuelven a presentárseles.

10 Recuperamos la expresión nativa "los biólogos", que es el modo en que los pescadores artesanales aluden a conservacionistas, veterinarios, biólogos y - mayormente - estudiantes de biología involucrados en el trabajo con las especies amenazadas. 


\section{ACERCA DE LA PESCA ARTESANAL}

San Clemente del Tuyú es el balneario más al norte de la costa bonaerense, situado a $300 \mathrm{~km}$ de la Ciudad Autónoma de Buenos Aires (figura 4). Sus poco más de 12.000 habitantes dependen fuertemente del turismo estival, fomentado por sus amplias playas y otros emprendimientos turísticos. A la sombra del turismo, sin embargo, se desarrolla otra actividad: la pesca artesanal.

Resulta difícil conocer el número exacto de pescadores que hay en San Clemente del Tuyú. ${ }^{11}$ A partir de la crisis socioeconómica sufrida por la Argentina en los años 2001 y 2002, muchos pobladores de San Clemente se volcaron a la pesca sin mayores conocimientos técnicos. A esto se suma el hecho de que la pesca es una actividad gobernada por las variaciones intrínsecas del recurso y el clima. La variación en la magnitud de las capturas conlleva a que muchos pescadores tengan una segunda ocupación (Elías et al. 2011). Si antes la caza era la actividad por excelencia en épocas de vacas flacas para la pesca, en la actualidad los pescadores trabajan de remiseros, ${ }^{12}$ guardavidas,

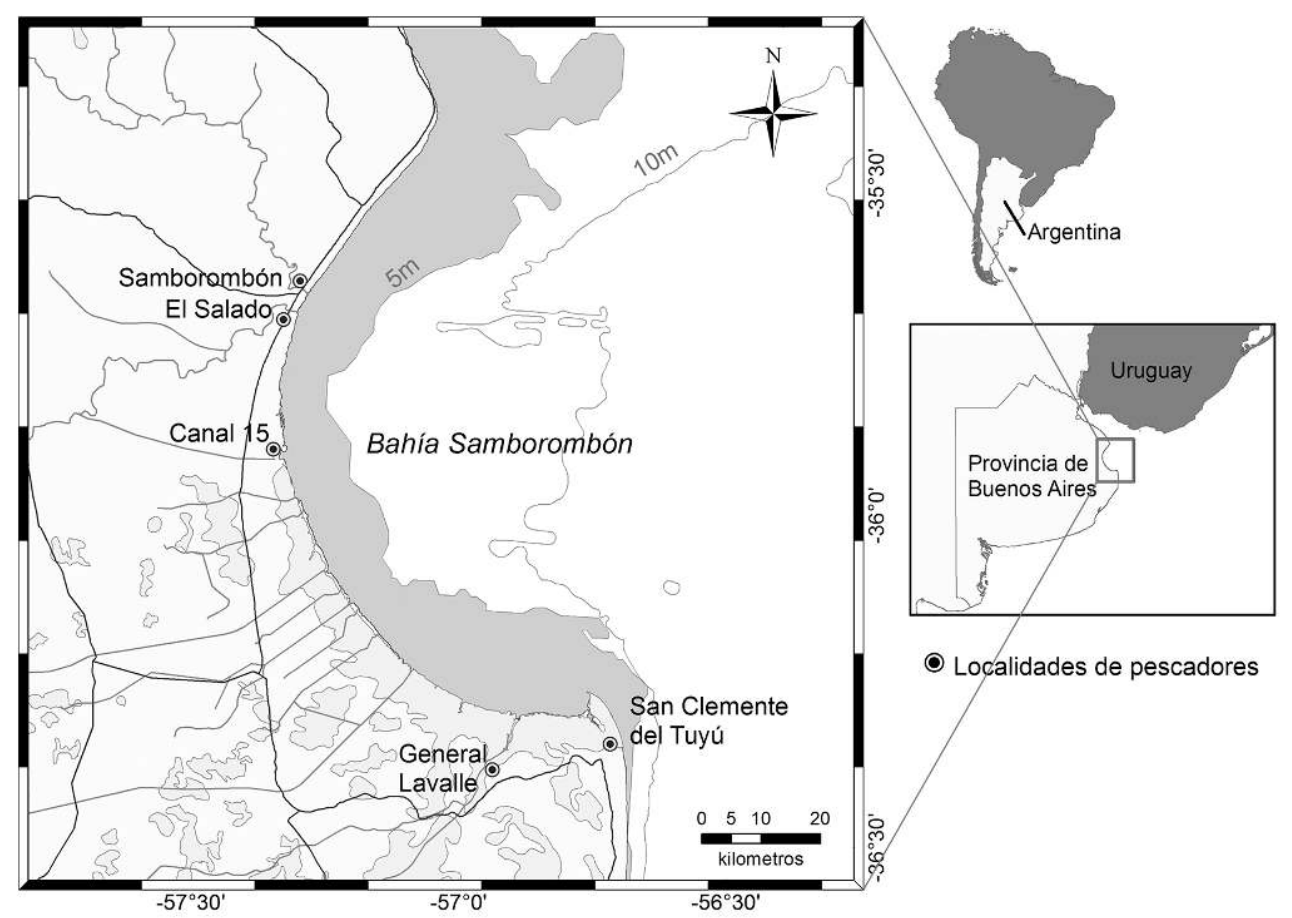

Figura 4 - La Bahía Samborombón y los principales puertos que albergan a la flota artesanal y a la semi-industrial procedente de Mar del Plata, Argentina.

11 San Clemente cuenta con aproximadamente 150 pescadores entre propietarios de lanchas, patrones y marineros.

12 Locución de Argentina y Uruguay. Persona que conduce un remise. 
carreros, ${ }^{13}$ empleados en el campo o de comercio. La mayoría de ellos procura, sin embargo, permanecer ligado al mar y al pescado, por lo que ocuparse como vendedor o filetero en alguna pescadería o frigorífico suelen ser las ocupaciones preferidas. ${ }^{14}$ Amén de estas prácticas y conocimientos divergentes al interior de la comunidad, las trayectorias económicas abarcan un vasto espectro desde el ex pescador que prosperó y administra su propia flota, hasta aquel que debe vender su fuerza de trabajo todos los días.

Los pescadores fluctúan en sus áreas y artes de pesca. En verano, algunos salen del puerto o de la playa hacia aguas a escasa distancia de la costa: 1 o 2 millas náuticas. Desde pequeñas lanchas de fibra de vidrio entre 6 y 8 metros de eslora (denominados trackers), pescan con redes de enmalle (figuras 2 y 5) (Lasta et al. 2001). La mayoría, sin embargo, se desplaza hacia áreas alejadas entre 50 y $100 \mathrm{~km}$ por tierra en las márgenes de la Bahía Samborombón, como por ejemplo Canal 15, el Río Salado y el Río Samborombón (figura 4). Allí pescan con sus propias embarcaciones o en otras de mayor porte - más de 10 metros de eslora -, con redes de arrastre de fondo a la pareja para capturar exclusivamente corvina rubia y pescadilla de red (figura 5). Este traslado implica vivir por un tiempo en campamentos precarios alejados de sus familias, y retornar

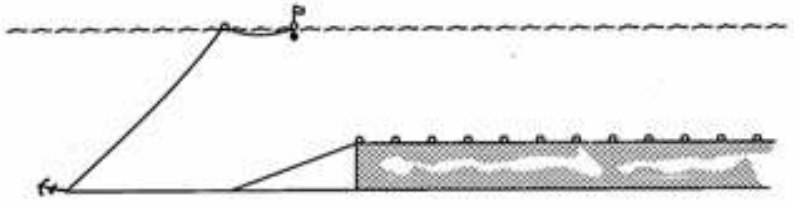

a)

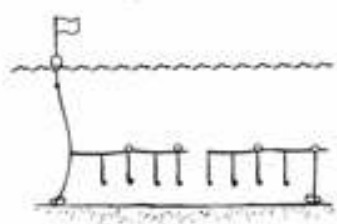

b)

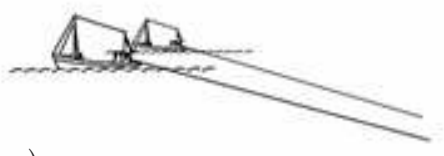

c)

Figura 5 - Artes de pesca utilizados en la Bahía Samborombón: a) red de enmalle de fondo, b) espinel, c) red de arrastre a la pareja. Imágenes obtenidas de Cousseau y Perrotta (1998).

13 Locución de Argentina. Persona que utiliza un carro tirado por un caballo para recolectar residuos urbanos, en especial cartón, o también arena de las playas para la venta.

14 Uno de los pescadores más antiguos de San Clemente tuvo, además de la pesca, una ocupación singular: a principios de la década del ' 80 , le fue encomendada la captura de una orca (Orcinus orca) y algunos delfines para su exhibición al público. El éxito de estas capturas y la gran adaptabilidad de los animales a las condiciones impuestas por el cautiverio le valieron un trabajo permanente durante 35 años, en el cual se ocupó de pescar en la bahía el alimento para la orca y los delfines. 
a San Clemente para dejar la ganancia recolectada. Los pescadores van, pues, donde el recurso "va". ${ }^{15}$

El invierno constituye el período más importante para la pesca en la Bahía Samborombón debido a las grandes biomasas de peces que se concentran (Lasta et al. 2001; Carozza et al. 2004): las capturas en esa estación pueden quintuplicar a las del verano, alcanzando en algunos casos los 6000 cajones - equivalente a 900 toneladas de pescado - por pareja de barcos. La bonanza del invierno es también aprovechada por otras flotas pesqueras provenientes del puerto de Mar del Plata que se trasladan hacia la Bahía Samborombón y se asientan en puertos cercanos como General Lavalle y el Río Salado (figura 4) (Lasta et al. 2001). Los pescadores de San Clemente conviven en estrecha cercanía con esas flotas costeras industriales y semi-industriales, con quienes libran una competencia desigual por la misma especie objetivo: la corvina rubia. El conflicto entre ambas flotas no solo se vincula con imprecisiones en la normativa pesquera actual (Errazti et al. 2009) - que perjudican a los pescadores artesanales -, sino también en la vulneración del territorio destinado a la pesca: "La flota grande entra y pesca en la milla cero. No respeta el límite, la profundidad, que haya redes, nada" [Alberto, pescador artesanal, 2013]. ${ }^{16}$

Amén de la pugna con la flota arrastrera foránea a la Bahía Samborombón, los pescadores artesanales de San Clemente del Tuyú lidian con una batería de expertos - biólogos, ONG, organismos del Estado - que tienen sobre los animales marinos una mirada disímil a la propia, y cuyas acciones retoman presupuestos de la política de conservación nacional e internacional. ${ }^{17}$ Para el caso de las especies de tortugas y mamíferos marinos que nos competen en este artículo, la Argentina reconoce su estado vulnerable y lleva adelante acciones de manejo y protección. Según la normativa vigente, está prohibido cazar delfines, lobos y tortugas marinas. El intercambio de estos o de cualquier parte de su cuerpo con fines comerciales - caparazones, pieles, dientes, huesos - está

15 Como señalan Ludwig et al. (en Pálsson 2001: 94), quizás sea más apropiado pensar que los recursos manejan a los humanos que lo contrario.

16 Los nombres de los pescadores entrevistados fueron modificados, intentando respetar su voluntad de anonimato.

17 Argentina adoptó compromisos internacionales sobre la preservación de la biodiversidad a través de numerosos tratados y leyes nacionales que bregan por el cuidado del medio ambiente y sus componentes. Entre los tratados se encuentra la Convención sobre la Conservación de las Especies Migratorias de Animales Silvestres, el Convenio sobre la Diversidad Biológica, el Código de Conducta para la Pesca Responsable de la Organización de las Naciones Unidas para la Alimentación y la Agricultura, la Convención sobre el Comercio Internacional de Especies Amenazadas de Fauna y Flora Silvestres y la Convención Interamericana para la Protección y Conservación de las Tortugas Marinas. Como ejemplo de leyes nacionales pueden citarse la Ley Nacional de Fauna Silvestre (N. ${ }^{\circ} 22.421$ ) - que declara de interés público la fauna silvestre del territorio argentino, así como su protección, conservación, propagación, repoblación y aprovechamiento racional - y la Ley general del Ambiente (N. ${ }^{\circ}$ 25.675), que establece los presupuestos mínimos para el logro de una gestión sustentable y adecuada del ambiente, la preservación y protección de la diversidad biológica y la implementación del desarrollo sustentable. 
también prohibido. Por otra parte, se promueve el uso de artes de pesca selectivos y seguros para el ambiente como modo de reducir los potenciales impactos negativos sobre especies que no son parte de su objetivo.

Ya sea en sus interacciones con la flota mayor o con los biólogos, los pescadores de San Clemente del Tuyú deben redefinir constantemente las acciones en pos de la explotación de los recursos pesqueros, a la cual va atada su subsistencia. Como veremos en la próxima sección, algunos de ellos fueron convocados para realizar una serie de ensayos para disminuir la captura incidental y la consiguiente mortalidad de especies marinas protegidas en las redes de enmalle.

\section{LA LLEGADA DE LOS BIÓLOGOS}

¿Cómo fue el proceso de introducir las especies frágiles "dentro del corazón y de la vida" ${ }^{18}$ de los pescadores? La literatura antropológica sobre las relaciones humano-animal en distintas sociedades enfatiza que existe un tratamiento distinto del animal según se lo considere o no parte de la misma comunidad moral de los humanos, vale decir: según la cercanía o la distancia social vivenciadas respecto de éste (Rival 2001). ${ }^{19}$ En ese sentido, una de las enseñanzas que los biólogos intentaron transmitir a los pescadores artesanales de San Clemente puede resumirse en el siguiente axioma: si un animal es cercano y querido, no debe ser matado. En la medida en que los pescadores pudieran sacar de la anonimia a las tortugas y los delfines, interiorizándose de su devenir y su calidad de sobrevivientes, acaso serían capaces de mirarlos con otros ojos y protegerlos. Quizás la recuperación de estas especies singulares atrapadas en las redes lograría instaurar, parafraseando a Rival (2001: 185), la cercanía apropiada con éstas, sintonizada con el diagnóstico de los expertos.

En el año 2004, AquaMarina ${ }^{20}$ inició un ensayo para evaluar la eficacia de un arte alternativo de pesca: el espinel (figura 5). A diferencia de las redes de

18 Referimos aquí al testimonio del nativo de las Islas Salomón citado al comienzo del trabajo.

19 En efecto, la utilización de un determinado arte de pesca - o tecnología de caza - nos da indicios del modo en que la naturaleza es objetivada o no por parte de distintos actores. En su estudio sobre la conexión entre la sociedad y la naturaleza de la cultura huaorani, Rival (2001) propone que los huaoranis utilizan dos tipos de armas para cazar animales, cerbatanas y lanzas, que definen dos relaciones sociales contrastantes. Las cerbatanas se utilizan para cazar monos que son reconocidos por los huaoranis como individuos. En cambio, las lanzas se usan para cazar pecaríes que son vistos como invasores agresivos, sociológicamente menos interesantes que los monos. De esta manera, la elección de la tecnología de caza de los huaoranis demuestra la relación que establecen con los animales.

20 AquaMarina (http://www.aquamarina.org/) es una agrupación establecida desde 1998 en Buenos Aires. Su trabajo se centra tanto en investigaciones científicas como en actividades de educación ambiental, con el objetivo de avanzar en la conservación de la biodiversidad y la salud de los ecosistemas costeros, a partir del uso sustentable de los recursos marinos. Estas actividades se realizan en colaboración con organizaciones locales e internacionales. En las iniciativas que se describen [continua] 
enmalle que utilizan regularmente los pescadores artesanales, el espinel resulta más selectivo: al capturar solo aquellos peces que comen de los anzuelos encarnados, se evita la captura de los delfines. El ensayo consistía en evaluar cualitativa y cuantitativamente la captura de peces y delfines en la red de enmalle y el espinel en una misma área de pesca. Para ello, observadores a bordo - mayormente estudiantes de biología, entre los cuales se encontraba una de nosotras debían acompañar a los pescadores en sus tareas diarias y registrar las especies capturadas, su cantidad y tamaño.

Para realizar el ensayo se debía contar con la ayuda de los pescadores, aunque no fue sencillo convocarlos. Si bien aquellos que participaran serían retribuidos con una modesta paga junto a otros beneficios como combustible o equipo de navegación, los pescadores objetaron la realización del ensayo preocupados por el futuro de su fuente de ingresos. Específicamente, los pescadores de San Clemente del Tuyú criticaron a los biólogos por las consecuencias que su trabajo había tenido sobre la comunidad de pescadores artesanales de Bahía San Blas, al sur de la Provincia de Buenos Aires. Para algunos pescadores, los biólogos eran responsables de que la pesca artesanal fuese prohibida en San Blas debido a los informes negativos presentados por estos últimos frente a las autoridades de pesca y fauna. ${ }^{21}$

Pese a los temores, algunos pescadores comenzaron con el ensayo de las redes y los espineles. Posteriormente, los más reticentes supieron que la prohibición de la pesca artesanal en San Blas había sido fruto de una confrontación entre pescadores artesanales y operadores turísticos locales centrados en la pesca deportiva. Los informes científicos - referidos a una gran variedad de especies de aves, moluscos y mamíferos marinos de la zona - habían sido utilizados en forma capciosa para sugerir el perjuicio de la pesca artesanal sobre las especies frágiles y favorecer al negocio de la pesca deportiva. Si bien perduraron algunos resquemores, el trabajo en conjunto entre biólogos y pescadores redundó en una realización exitosa del ensayo y una atenuación mutua de los resquemores (figura 6).

En efecto, las horas de embarque transcurrían en un ameno intercambio de conocimientos entre biólogos y pescadores, a fin de fomentar un apropiado ritual de captura que minimizara el daño y evitara las matanzas innecesarias. Los biólogos comentaban algunos hábitos curiosos de las especies protegidas: sus migraciones de miles de kilómetros; su lejana convivencia con especies ya

en este artículo, AquaMarina contó con el apoyo financiero y técnico de ONG internacionales como la World Wildlife Fund (WWF, a través del Programa Marino de la Fundación Vida Silvestre Argentina) y la Wildlife Trust, entre otros.

21 Respecto de las distintas miradas sobre el conflicto de San Blas por parte de pescadores, ONG, biólogos y abogados ambientalistas, véase el n. ${ }^{\circ} 129$ de la Revista de la Fundación Vida Silvestre Argentina, octubre-diciembre 2014, disponible en < http://www.vidasilvestre.org.ar/sala_redaccion/opublicaciones/revista_fvsa/? 1 1860/Revista-de-Vida-Silvestre-129---Octubre---Diciembre-2014 >. 


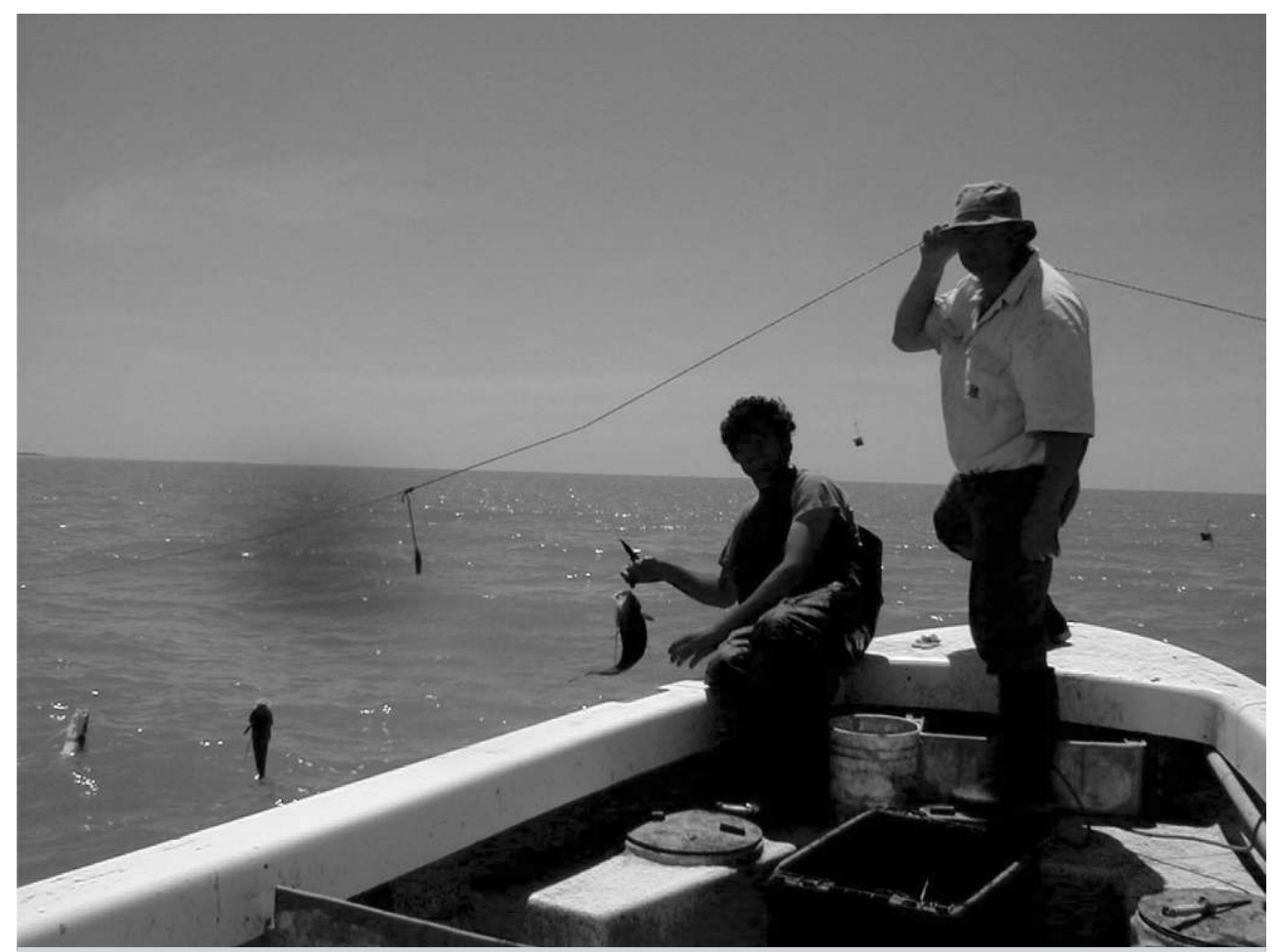

Figura 6 - Pescadores artesanales de San Clemente del Tuyú trabajando con el espinel. Foto: AquaMarina.

extintas como los dinosaurios; y el origen terrestre de los delfines. Los pescadores, por su parte, ilustraban a los biólogos acerca de cuestiones no menos asombrosas: peces que roncan o saltan fuera del agua; "chuzas" o espinas de bagre que desfallecen al que se las clava por accidente y aguas que "no caminan". ${ }^{22}$

Aunque el ensayo con el espinel se centró en el delfín franciscana, la interacción con otros equipos de trabajo ${ }^{23}$ hizo que también se prestara atención a otras especies afectadas. Los observadores a bordo debían registrar si la red y el espinel afectaban también a las tortugas marinas. El trabajo conjunto a bordo se complementaba con visitas diarias al puerto de San Clemente en horas en que se arribaba con la pesca del día: allí, otros pescadores no involucrados en el ensayo aportaban más información a partir de tortugas vivas y muertas que traían a pedido de los biólogos. Como única retribución, los pescadores

22 Los pescadores suelen decir que "el agua no camina" en la estoa, periodo de tiempo entre una marea baja y alta, y viceversa.

23 En ese entonces, el recientemente formado Programa Regional de Investigación y Conservación de Tortugas Marinas de Argentina (PRICTMA) comenzaba a desarrollar sus primeras actividades de monitoreo de puertos y playas en busca de registros de estos reptiles. 
solicitaban los caparazones para vendérselos a los turistas. Si décadas atrás los pescadores vernáculos acostumbraban vender carne de delfín franciscana a una comunidad coreana que residía en General Lavalle, ${ }^{24}$ la venta de los caparazones permitía aprovechar lo que de otra forma hubiese sido descartado en el mar, o arribado putrefacto a las playas sanclementinas.

El ensayo demostró que los espineles no solo reducían la captura incidental de delfines y tortugas - al menos en esa escala experimental -, sino que incluso las piezas capturadas por el espinel eran de mejor calidad que las de la red (Bordino et al. 2006). Aunque la biomasa de pescado fuera menor, el espinel capturaba pescadilla de red, corvina y brótola (Urophycis brasiliensis) - especies valoradas en el mercado - y no así saraca (Brovoortia aurea), que es de escaso valor comercial y suele destinarse para harina de pescado. Asimismo, los peces enganchados en los anzuelos permanecían vivos mientras estuvieran en el agua, por lo que llegaban frescos a la costa. ${ }^{25}$ La calidad superior del pescado de espinel abría la posibilidad de desarrollar un mercado local en donde este producto fuese valorado, vendiéndose más caro que el pescado de la red, y promoviendo un mayor uso de este "nuevo" arte de pesca por parte de los pescadores. No obstante las supuestas ventajas económicas, la aceptación del espinel estuvo lejos de ser la esperada. Los pescadores, además, dieron nuevos significados a esa práctica conservacionista, tal como veremos en la próxima sección.

\section{EL POTENCIAL SIMBÓLICO DE LAS ESPECIES}

Para los biólogos que lo propiciaban, el cambio del arte de pesca habría de instaurar una relación menos agresiva con la especie considerada frágil. Para los pescadores, en cambio, el ensayo con el espinel no hizo sino trasladar la agresión hacia ellos mismos, al mismo tiempo que les causaba un perjuicio económico.

"El espinel no funciona porque es riesgo para la vida del marinero, y eso no sirve. Salvo que se tiren muchos más anzuelos y esté automatizado el sistema" [Esteban, pescador artesanal, 2014].

“[El espinel] son más horas hombre, más riesgo. Si bien es menor el costo del equipo [en comparación con las redes], el marinero no te quiere trabajar con el espinel por 150 pesos que se lleva a la casa" [Alberto y Bernardo, pescadores artesanales, 2013].

24 Los locales lo denominan a la carne de delfín "muchame" o "mushame", en alusión a un plato tradicional peruano que se elabora con carne de atún salada y secada al sol. En Perú, también se conoce con ese nombre al plato elaborado con carne de delfín.

25 El pescado de las redes, por el contrario, suele quedar aplastado por la misma fuerza del agua y por ende no llega en tan buen estado. 
¿Qué motivó entonces a los pescadores a avenirse - y eventualmente someterse - al saber experto de los biólogos, pese a que esta nueva técnica suponía un potencial peligro no solo para su medio de subsistencia, sino para su propio cuerpo? Nuestra hipótesis es que los pescadores dotaron de nuevos sentidos a la práctica conservacionista de la cual participaron. No fue una fe conservacionista a priori lo que los movilizó, así como tampoco un simple interés económico por la paga que recibían de tanto en tanto. Si bien su participación redundó en algún beneficio económico inmediato, esta puede ser mejor comprendida en términos de reciprocidad, vale decir: aquello que yo aporto hoy, acaso me sea retribuido mañana en igual o mayor grado. Más concretamente, si "las aguas bajan turbias" y surgen restricciones a la pesca artesanal, acaso sea útil contar con la amistad de un biólogo que proteja los intereses de los pescadores frente a actores poderosos que definen las reglas del juego, tales como la Subsecretaría de Pesca de la provincia de Buenos Aires, el Consejo Federal Pesquero o el Ministerio de Agricultura, Ganadería y Pesca de la Nación. Al explicar el por qué de su participación en los proyectos de los biólogos, los pescadores argumentan: "[Si] vos trabajás para una fundación, ya estás trabajando a favor de la bahía [...] Teníamos un apoyo en caso de que pasara algo" [Bernardo, pescador artesanal, 2014].

Desde la perspectiva de los pescadores, ellos son el eslabón más débil de la cadena y nadie sale en su defensa. Bajo una coyuntura de relativo aislamiento, mal pueden negarse ellos a sumar aliados honorables. Su participación en la protección de estas especies carismáticas les permite visibilizarse ante las autoridades respecto de los problemas que los afectan en lo inmediato - como la aparente sobreexplotación del recurso realizada por los arrastreros - o bien que pueden aquejarlos en el futuro: el establecimiento de áreas de veda o la prohibición de la pesca artesanal.

Durante el ensayo con esta "nueva" y controvertida arte de pesca, los pescadores supieron del altísimo valor que otros actores atribuyen a las tortugas y delfines con las que ellos tienen un contacto regular. El status ordinario de los cruces con esas especies pasó a revestir una renovada aura, como un campesino que ha apreciado toda su vida, frente a la chimenea de su casa, un cuadro heredado de sus padres, sin saber aquello que el mundo exterior iba a descubrir en él: las pinceladas únicas, sagradas de un Van Gogh. Aquellas relaciones privadas, anónimas - entre los pescadores y las tortugas, entre el campesino y su tela - quedan ahora expuestas frente a ojos científicos que vigilan o prescriben el tratamiento de ese bien patrimonial.

Embebidos ahora de la relevancia "objetiva" de tales especies, algunos pescadores practicaban pequeños rituales para inmortalizar los actos de recuperación de tortugas o delfines. A lo largo de los diez años de relación entre biólogos y pescadores, sacarse fotos o filmarse en cubierta con las tortugas recuperadas vivas de sus propias redes, o bien liberarlas acompañados de sus 
esposas e hijos se tornó una experiencia común. Algunos pescadores bautizaron a las tortugas con el nombre de sus hijos; uno de ellos incluso las mantenía en una pileta para bebés a la espera de que algún biólogo la fuera a buscar. ${ }^{26}$ A esto se sumó la exhibición de fotos de liberaciones de tortugas y delfines en las pescaderías. A modo de trofeo, los caparazones decoran las vidrieras de las pescaderías cercanas al puerto, desnudos o convertidos en relojes artesanales: paradojas de un animal que representa el tiempo detenido (figura 7). Aquellos objetos-símbolo no permanecen, por lo general, en la intimidad del hogar sino en la vitrina adecuada para demostrar, tanto a sus pares como a un público amplio, sus dotes como pescadores, y por qué no, como conservacionistas.

Algunos pescadores se anticipaban a lo que los biólogos querían escuchar, enhebrando minuciosamente en su discurso lugares comunes de la sustentabilidad tales como el "colapso del recurso", la "preservación de una especie" o el "bycatch" 27 de delfines. Estos relatos encajaban con las expectativas de los biólogos acerca de lo que debía ser un pescador artesanal que hiciera "honor a su oficio". Los pescadores devenidos más conservacionistas que los

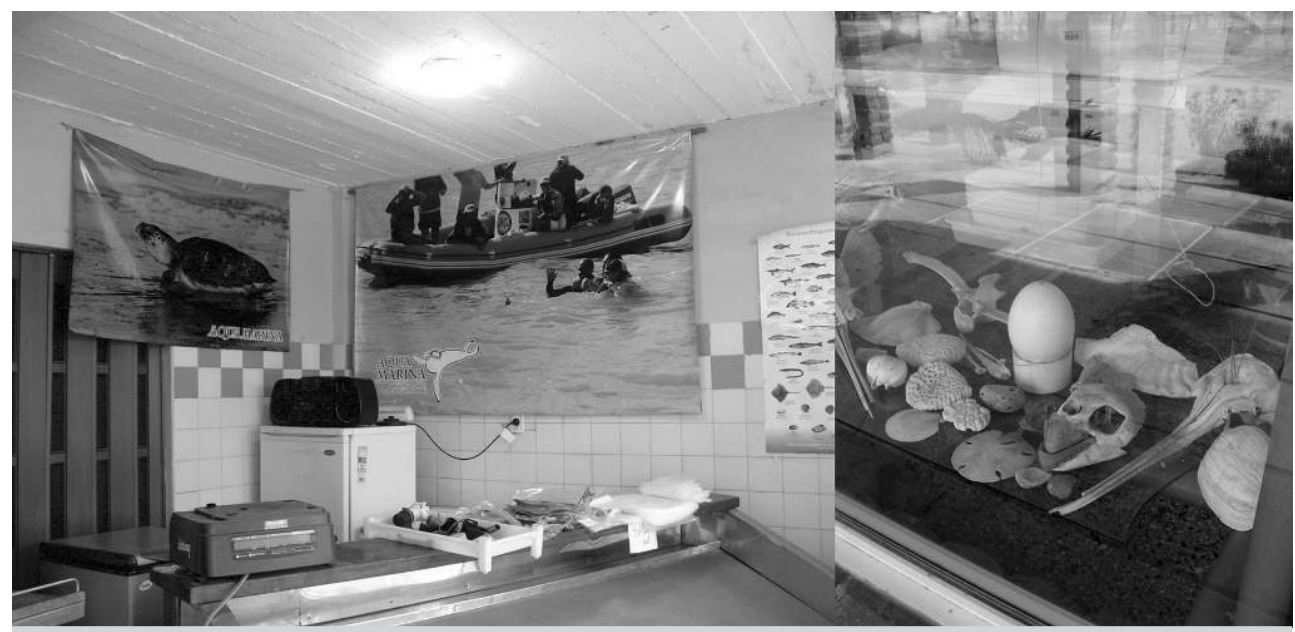

Figura 7 - Imágenes y restos de tortugas y delfines que decoran las pescaderías en San Clemente del Tuyú. Fotos: María Carman y Victoria González Carman.

26 Aquí vale la pena recordar a Mario, un afamado pescador de la localidad de Villa del Mar, al sur de la provincia de Buenos Aires, que si bien no participó de los ensayos con los espineles, estuvo siempre en contacto con biólogos preocupados por la conservación de la fauna marina, en especial las tortugas. Mario impartía charlas sobre conservación en su pueblo y hasta llegó a plotear el capot y baúl de su carcomido Peugeot 405 con dibujos de las tortugas, junto a logos de organizaciones conservacionistas.

27 Bycatch es el término que se utiliza en inglés para denotar la captura incidental. 
conservacionistas ${ }^{28}$ y cuyo diestro uso de la jerga biológica complacía a los biólogos, eran blanco de críticas de sus pares, quienes los consideraban charlatanes o malos pescadores.

La adhesión de los pescadores a la "causa ambiental" distaba de ser unánime. Desde el momento en que los biólogos comenzaron con los ensayos del espinel, algunos pescadores no dejaron de demostrar su oposición, fundamentada en gran medida en los sucesos de San Blas: "Yo nunca trabajé con ellos. A mí no me interesa que me des 3000 pesos y después me cagues la vida. Por salvar a un franciscano, me matás a mí" [Adolfo, pescador artesanal, 2014].

Pese a estas diferencias, la mayoría de los pescadores se esforzaba por transmitir una imagen de sí vinculada a una responsabilidad ambiental. Como cualquiera de nosotros, ellos sub-comunican los aspectos negativos y resaltan aquellos rasgos que sus interlocutores anhelan encontrar.

\section{UN CONSERVACIONISMO ESTRATÉGICO}

Como vimos hasta aquí, una especie frágil puede representar para los pescadores tanto un recurso - a partir de la venta de los caparazones, por ejemplo - como una amenaza a la subsistencia, signado por el antecedente de San Blas. A partir del contacto con los biólogos, el delfín y la tortuga adquieren un potencial simbólico mediante el cual los pescadores suman credenciales conservacionistas, que bien pueden asociarse al paradigma paternalista descripto por Pálsson (2001) al comienzo del artículo. Sin embargo, la práctica de conservación de las especies amenazadas jamás significó lo mismo para uno y otro grupo de actores.

El intercambio entre biólogos y pescadores genera en estos últimos una serie de obligaciones no escritas, aunque sobreentendidas, como cesar de lucrar con esas especies y protegerlas bajo los cánones de los primeros. Si bien algunos pescadores continúan vendiendo los caparazones de tortuga en forma clandestina, no creen que ese mínimo lucro con un animal que ya está irremediablemente muerto - y al cual ellos no mataron intencionalmente - traicione su adhesión a un ideario conservacionista. El trabajo en pos de una especie frágil no modifica su necesidad de pescar lo más posible para subsistir. "Nosotros siempre los cuidamos", nos aclaran los pescadores, en referencia a su histórico trato con delfines y tortugas.

El aprovechamiento económico de las especies marinas por parte de los pescadores desentonaba con el romanticismo que movilizaba a los estudiantes

28 En uno de los viajes a San Clemente, un pescador ofrece a una de nosotras traerle tortugas para sus investigaciones. Ante la explicación de que ahora nuestro foco de interés no eran las tortugas sino las relaciones entre seres humanos y especies animales, una pescadora que presenciaba la charla interrumpió graciosamente: "Dejala, no quiere. iNo ves que se está expandiendo!" 
de biología a participar voluntariamente del ensayo con el espinel. El activismo conservacionista de estos jóvenes - motivado por la belleza de las especies y su fragilidad al ser "muertas injustamente" en las redes - convivía con la certeza científica de que la diversidad de organismos es buena y posee un valor intrínseco: ${ }^{29}$ "Para mí cada franciscana que se moría era un animal más que aumentaba la mortalidad y perjudicaba a la población” [Laura, bióloga y esposa de pescador artesanal, 2014].

El hecho de que la reproducción de los pescadores estuviese atada a un recurso marino, sumado a sus pasados "non sanctos" como cazadores de nutrias, chanchos salvajes o venados, los volvía a los ojos de los voluntarios casi irredimibles. Esta situación se agravaba cuando los pescadores mataban a tiros de escopeta a los lobos marinos que se entrometían en la red, frente a los ojos azorados de los estudiantes de biología: “iSe me caían las lágrimas y no podía decir nada! Pero para ellos [los pescadores] era un animal que les rompía las redes y les salía tanta plata" [Laura, bióloga y esposa de pescador artesanal, $2014]$.

Los voluntarios consideraban que los pescadores difícilmente pudieran sostener en el tiempo un compromiso ecológico no solo por su presunta ignorancia sobre la "crisis de la biodiversidad" en general, y del frágil estado de conservación de los delfines y tortugas en particular, sino también por el "oportunismo" 30 que, en apariencia, motorizaba las acciones de estos últimos.

Lo interesante es que el estigma de oportunistas es desplazado por los viejos pescadores hacia los "nuevos", calificados como meros "juntadores de pescado". A ellos no les interesa "cuidar el recurso", sino "llenar la lancha" cuando hay buenas zafras: "Salen sólo si hay pescado. Así es fácil, no te rompen una red, no te gastan nafta, nada [...] iTe ponen las redes adelante tuyo! Al no ser del oficio, hay ciertos códigos y manejos que no conocen, no respetan" [Alberto, pescador artesanal, 2013].

Pese a la "conversión" de muchos pescadores, los voluntarios siguen considerando a los primeros como "conservacionistas inauténticos". Para los biólogos o estudiantes de biología, los pescadores jamás serán capaces de sentir el

29 Estos son algunos postulados de la biología de la conservación, una disciplina que surge como respuesta de la comunidad científica a la crisis de la biodiversidad global. Para alcanzar la protección y gestión de la biodiversidad, esta disciplina retoma principios y experiencias de otros campos del saber - como la biología, genética, ecología, el manejo de recursos naturales -, así como también de las ciencias sociales - como la antropología, la sociología, la filosofía y la economía -, y las artes (Groom et al. 2006).

30 Los pueblos cazadores y recolectores también suelen ser calificados peyorativamente como oportunistas: estos, en apariencia, toman lo que quieren y cuando quieren (Ingold 2000: 71). No obstante, este oportunismo es malinterpretado, ya que no se trata de tomar lo que se quiere, sino de aceptar lo que es dado (Ingold 2000: 71). 
amor desinteresado hacia la naturaleza que ellos forjaron en la universidad, las campañas, el activismo, o incluso durante su infancia.

Cierto abismo de clase - expresado en diferencia de capitales, trayectorias, oportunidades y competencias - es sublimado como mera diferencia cultural. Bajo la perspectiva de ciertos militantes de la conservación marina, solo una elite de entendidos sabrá valorar los tesoros que el mar esconde entre sus olas o en sus oscuras profundidades. Si en aquel podio de sensibles ha de figurar algún sector perteneciente a las clases sociales más desfavorecidas, ciertamente no será un proletario o un trabajador independiente que "depreda los recursos naturales" sino, en el mejor de los casos, un indígena, resabio contemporáneo del buen salvaje. ${ }^{31}$

Los pescadores de San Clemente - o al menos una porción significativa de ellos - pueden ser definidos como conservacionistas estratégicos al menos en tres sentidos. En primer lugar, los pescadores desafían el purismo de los biólogos y su exclusiva preocupación por "los bichos" - las tortugas y los delfines con un amplio repertorio de burlas, provocaciones y sarcasmos, afirmando que se han comprado nuevos barcos para matar todas las tortugas o que tienen planeado tirar incontables metros de red. Su incorporación de cierto ethos ambiental no está exenta de una discreta distancia provista por la ironía: "Si estaba viva la soltaba... pero tampoco me iba a poner a llorar cada vez que veía una tortuga, ¿eh?" [Bernardo, pescador artesanal, 2014].

En segundo lugar, el conservacionismo de los pescadores difiere del de los científicos en el siguiente aspecto: los primeros creen que existe poca o nula influencia del obrar humano sobre las fuerzas naturales. Nuestro trabajo de campo cuenta con sobrados ejemplos del respeto hacia las fuerzas del mar y el clima por parte de la comunidad de pescadores: se trata de poderes de la naturaleza que no corresponde desafiar.

Marina, una ex pescadora - cuya pertenencia a la comunidad estuvo signada por ser la hija de un respetado pescador, así como la esposa de otro - recuerda los accidentes a causa de sobrecargar la lancha durante malas condiciones climáticas, lo cual equivale a perder la humildad frente al océano: "El clima no lo podés controlar, lo aceptás como es. Si lo controlás, ahí es cuando pasan los accidentes". Esto resultaba particularmente cierto en aquellas épocas de los inicios en que se disponían de menos herramientas tecnológicas y estaban, según la expresión nativa, "a merced del remo".

En términos de Bourdieu (1991), lo que varía es el grado de autonomía concedido al obrar humano. Si los conservacionistas imputan a los humanos una agencia significativa, en el caso de los pescadores esa autonomía se ve

31 Existe una vasta literatura sobre la idealización de los indígenas como seres más próximos a la naturaleza. Véase al respecto Little (1999), Latour et al. (1991: 34), Descola (2005 [2001]), Carman (2011: 146-161) 
supeditada a esas imponderables fuerzas de la naturaleza. Los hombres deben mantener, desde esta última visión, un balance apropiado en las relaciones de ellos mismos con esas fuerzas. ${ }^{32}$

En tercer lugar, la interacción con los biólogos representa - para algunos de los pescadores - la posibilidad de aumentar su capital social y simbólico. ${ }^{33}$ Si colaboran con ellos, podrán controlar mejor los informes que estos producen sobre su práctica de pesca. Recordemos además que los pescadores objetan la inacción de los biólogos frente a una de las problemáticas que más complica su subsistencia: las prácticas predatorias de los recursos ictícolas por parte de las flotas más grandes a las cuales nadie toca porque son la postal de Mar del Plata.

En junio del 2014, los pescadores artesanales bloquearon el puerto de General Lavalle y la ruta interbalnearia debido a que la veda de corvina rubia - recientemente establecida por el Ministerio de Asuntos Agrarios bonaerense para proteger el recurso - los perjudicaba únicamente a ellos; mientras que los arrastreros de Mar del Plata podían explotar el recurso sin restricciones. ${ }^{34}$ Con una mezcla de impotencia e ira, un pescador de San Clemente del Tuyú recuerda aquellos días: "Estuvimos un mes y diez días sin poder pescar, mientras los barcos de afuera venían, pescaban, se iban, y nosotros nos moríamos de hambre" (Agencia de Noticias NOVA de Mar del Plata, 30 de julio de 2014).

Como señalamos antes, la práctica conservacionista propuesta por los biólogos se mantiene ajena a una de las preocupaciones más acuciantes de los pescadores: el conflicto que mantienen con la flota semi-industrial proveniente de Mar del Plata y la ausencia de regulación estatal al respecto. Desde una perspectiva conservacionista tradicional, los humanos son vistos como externos al ecosistema y la crisis ambiental es el resultado de la acción destructiva de los humanos sobre la naturaleza, lo cual redunda en una escasa atención a la utilización socialmente inequitativa de los recursos naturales (Nygren 1999: 272).

32 En el mismo sentido, los cazadores y recolectores establecen una relación de confianza (trust) con las agencias y entidades del ambiente de las cuales dependen. Esto implica el riesgo de que el otro - cuyas acciones no pueden controlar - actúe de manera contraria a sus expectativas (Ingold 2000: 69-72).

33 Aquellos pescadores más estrechamente ligados a AquaMarina tuvieron la posibilidad de participar en proyectos de investigación y conservación en el exterior, por ejemplo en las capturas de delfines con fines científicos que se llevan a cabo desde hace más de 30 años en la Bahía de Sarasota en Florida, Estados Unidos. Asimismo, algunos pudieron asistir a reuniones científicas en las cuales contaron sus experiencias acerca del trabajo con especies protegidas, y se contactaron con pescadores artesanales de otros países, como Uruguay y Brasil.

34 Las embarcaciones pequeñas como las artesanales no pueden navegar a partir de los límites dispuestos por la veda (7 millas náuticas de la costa), a diferencia de la flota mayor que sí está habilitada y puede pescar ejemplares juveniles en altas proporciones. 


\section{UN ORIENTALISMO A PEQUEÑA ESCALA}

¿Cuáles son los límites de este conservacionismo estratégico de los pescadores artesanales? Lejos de cualquier romanticismo ecologista, los pescadores subsumen a los animales con los que interactúan a la dicotomía de "especie útil" o "no útil". Esta caracterización puede extenderse a otros animales con los que se relacionan fuera del mar y las rías, ya que en las mismas familias de los pescadores hay quienes trabajan con el carro y el caballo vendiendo arena de las playas a obras en construcción.

Nuestros entrevistados manifestaron que su pez favorito para pescar es el que tiene más valor económico. Por el mismo motivo, la captura no intencional de los delfines y las tortugas es básicamente un desperdicio. "Te da pena porque no sirve para nada. Para sacarle el caparazón, ¿ ipero cuánto podes ganar? Si se pudiera aprovechar sería distinto" [Raúl y Gustavo, pescadores artesanales, 2013 y 2014$]$.

Esta visión antropocéntrica de concebir a las especies como un recurso se corresponde con el paradigma orientalista propuesto por Pálsson (2001: 87), del cual ya dimos cuenta en la introducción del trabajo. No obstante, los pescadores artesanales encarnan lo que podemos denominar un "orientalismo a pequeña escala”, que difiere de la explotación intensiva propia de una flota industrial. Si bien tanto los pescadores artesanales como la flota semi-industrial utilizan artes de pesca poco selectivos comparados con el espinel, el daño que los primeros provocan a las poblaciones de peces y a su hábitat resulta mínimo en comparación con el de la flota mayor. ${ }^{35}$ Regulando el tamaño de malla de la red de enmalle o eligiendo cuidadosamente el sitio de calado, los pescadores artesanales pueden evitar capturar peces juveniles. Bajo esta perspectiva orientalista a pequeña escala, la idea de "matar para comer" (Århem 2001: 232) no resulta incompatible con la búsqueda de regeneración de esas vidas depredadas a partir de prácticas que evitan la captura de peces muy pequeños o la utilización de artes de pesca que no destruyan el ambiente.

El orientalismo a pequeña escala es incluso evidente en aquellos pescadores que, como señalamos antes, se dedican a la pesca de arrastre durante el invierno. "Yo voy a pescar y si puedo traer pescado hasta el techo, lo traigo", nos explica un pescador. Si bien esta práctica predatoria podría pensarse a priori como una situación ventajosa para los pescadores, la misma no está exenta de contrapuntos. En el caso de los pescadores que se emplean como marineros en

35 La red de arrastre de fondo es aún menos selectiva que la red de enmalle y daña el lecho marino del cual dependen los peces para alimentarse y reproducirse. Se trata de un arte de pesca activo (contrario a la de enmalle que es pasivo) que va al encuentro del cardumen. Como una bolsa, es remolcada por el fondo marino durante un período de tiempo. Si bien puede regularse la luz de malla de la red para evitar la captura de peces juveniles, a medida que se arrastra la captura se acumula, reduciendo significativamente la luz de la misma y la posibilidad de que los mismos escapen. La malla suele obstruirse además por peces que quedan atrapados (FAO 2005). 
un barco arrastrero, existe un delicado balance entre varios factores: la seguridad de contar con un sueldo independientemente de lo que se pesque - renunciando a una ganancia potencialmente mayor como patrón -, y un alivio al desgaste físico durante las tareas de pesca, en oposición a la precariedad de los campamentos en donde viven, alejados de sus familias. La pesca de arrastre llevada a cabo por los pescadores artesanales es incluso controversial en el seno mismo de este sector, ya que algunos de ellos - en sintonía con la postura de la Unión Argentina de Pescadores Artesanales ${ }^{36}$ - la consideran uno de los grandes problemas a resolver en pos de lograr una pesca sustentable.

Otra de las características distintivas de este orientalismo a pequeña escala es que los pescadores de San Clemente no solo conciben al pez o la tortuga como un recurso a explotar, sino también a su propio cuerpo. "Cuando estoy allá afuera y me duele la cadera, sigo. Si estoy cansado, sigo. Si hace frío, sigo. Si estoy mojado, sigo. El cuerpo lo siente mucho" [Bernardo, pescador artesanal, 2014].

Como el "tiempo de pesca" es acotado, y no siempre hay buenas temporadas, el cuerpo debe ser aprovechado sin pausa en desmedro de huesos y articulaciones.

Urbi et orbi, los pescadores exponen día a día su cuerpo a las inclemencias del tiempo y a las demandas físicas de esa actividad. Esta valoración del cuerpo como herramienta que debe utilizarse al máximo resulta usual en los sectores populares, y ha sido analizada en detalle en un trabajo clásico de Boltanski (1975): ¿cómo ser resistente al dolor? ¿Cómo hacer "funcionar" el cuerpo durante el mayor tiempo y con la mayor intensidad posible? ${ }^{37}$

Si la relación que los pescadores traban con las especies en su vida cotidiana es frecuentemente descripta por ellos en términos instrumentales, pues la "relación" con el propio cuerpo también lo es.

\section{EL COMUNALISMO IMPLÍCITO}

"El espesor del cuerpo, lejos de rivalizar con el del mundo, es, por el contrario, el único medio que tengo para ir hasta el corazón de las cosas,

36 La Unión Argentina de Pescadores Artesanales es una asociación civil que nuclea a todos los pescadores artesanales de las cinco provincias con litoral marítimo de Argentina, y en la cual participan como miembros activos algunos pescadores de San Clemente.

37 " $[\ldots][\mathrm{L}]$ a idea de fuerza $[\ldots]$ nunca explicitada ni sistematizada, constituye el principio de coherencia de todo un conjunto de actitudes aparentemente independientes" (Boltanski 1975: 66). En efecto, el cuerpo habla incluso cuando uno no quiere que hable, nos advierte Bourdieu, en tanto designa no solo la posición actual sino también la trayectoria. "La distribución desigual de las propiedades corporales entre las clases se realiza a través de mediaciones tales como las condiciones de trabajo $[\ldots]$ y los hábitos de consumo. [...] [L]a relación con el propio cuerpo es [...] una forma particular de experimentar la posición en el espacio social [...]" (Bourdieu 1986: 184). 
convirtiéndome en mundo y convirtiéndolas a ellas en carne" (Merleau -Ponty en Citro 2010: 40).

Pese al pragmatismo que los pescadores de San Clemente exacerban frente al interlocutor foráneo, ellos no perciben al mar y a los animales como un escenario imparcial donde se consuma una matanza. Aunque a primera vista parezca un contrasentido, el discurso de la explotación del recurso arraiga no solo en una práctica de cotidiana intimidad con las especies sino en una ubicua interacción con el entorno natural, cuyas vicisitudes teje también la trama de sus vidas. Siguiendo el esquema de los tres paradigmas de Pálsson, esta experiencia práctica de los pescadores bien puede ser definida como un comunalismo. ${ }^{38}$ Más precisamente se trata, en nuestros términos, de un "comunalismo implícito": los pescadores entablan un diálogo sin fin con el mar que les da y les quita, así como con los animales que van y vienen; vivencia que se expresa menos en palabras que en actos. Entre sus principales características, podemos señalar las siguientes.

\section{a) La antropomorfización de los animales}

Como vimos en el apartado anterior, las narrativas de los pescadores homologan aquellos recursos sobre los que pesa una vocación maximalista de explotación: las distintas especies de peces, aunque también el propio cuerpo. Así como la fisicalidad de pescado y pescador comparten un campo semántico, lo mismo sucede con la interioridad de los humanos y aquella de las especies frágiles: estas son calificadas con metáforas humanas en pos de su proximidad con el propio agente enunciativo.

Ante la pregunta de por qué quedan atrapados los animales en las redes de enmalle, los pescadores responden unánimemente que "el franciscano viene boludeando ${ }^{39}$ y se agarra en la red". En contraste con biólogos y conservacionistas que ponderan la inteligencia de los delfines, los pescadores saldan la cuestión sin rodeos: "son re tontos: se mueren en seguida". "El franciscano no tienen la posibilidad de aprender, porque se enganchó y se murió. Viene a jugar con las boyas. Se engancha por eso" [Alberto, pescador artesanal, 2013].

En cambio, las tortugas "son más duras", ya que muchas veces son encontradas vivas, enganchadas de la cabeza o las aletas. "Las tortugas al principio quedan apoyadas en la red, la misma correntada las mantiene apoyadas. Si aguanta, si puede salir a respirar, cuando cambió la marea se va. Pero la que se enmalló quedó ahí. Si se enmalla abajo [de la red], se muere; si se enmalla arriba, se va" [Bernardo, pescador artesanal, 2013].

38 Aunque no es mencionada bajo estos términos, la cosmovisión comunalista es agudamente descripta por Bird-David (1992).

39 Locución de Argentina y Uruguay. Perder el tiempo. 
Sólo las redes de arrastre parecen ser más peligrosas para las tortugas, ya que son atrapadas cuando están "durmiendo en el fondo". El delfín, en cambio, "se asusta con el ruido del motor, va ligero y se escapa".

A diferencia de estos inocuos animales, los lobos marinos despiertan sentimientos de odio. Si bien son "el enemigo número uno" porque "aparecen y no hay pescado", o "te rompen todo" y "te funden", los pescadores no dejan de admirar su astucia e inteligencia:

"Yo te aseguro que vos agarrás un lobo, lo soltás a 50 kilómetros y al otro día está acá de nuevo. Es más rápido que nosotros... iqué instinto el del animal!" [David, pescador artesanal, 2013]

"Los lobos de acá tienen hecho un curso de computación" [Adolfo, pescador artesanal, 2014].

"Encima por ahí cambiás de zona [de pesca] y te siguen los desgraciados" [Eliana, ex pescadora artesanal, 2014].

Mientras los pescadores revisan su red, no resulta inusual que vean asomar las oscuras cabecitas de los lobos en el mar, a poca distancia del extremo opuesto de la red. Acto seguido, el triste hallazgo de cabezas de pescado en la red, sin cuerpo, junto a agujeros "tan grandes como la cancha de Boca". ${ }^{40}$

Los pescadores clasifican constantemente a los animales de su entorno según su inteligencia o estupidez: si el lobo marino es inteligente porque logra comer el pescado de las redes sin engancharse y esquivar los escopetazos propinados desde la lancha, el delfín es tonto porque no aprende y queda atrapado en la red. Esas cualidades intelectuales reflejan, además, la distancia de esas especies respecto de ellos mismos. No se trata, sin embargo, de un etiquetamiento rígido. Al calor de las circunstancias, los pescadores se "enojan" o "amigan" con estos animales precisamente porque se trata de un vínculo de intensa intimidad. Conocer a alguien significa, para los cazadores y recolectores, ser sensible a sus gustos, reacciones, humores e idiosincrasias (Ingold 2000: 72). Esto incluye, claro está, a los diversos seres del reino animal.

\section{b) Una taxonomía afín a la experiencia práctica}

Sabemos también que los pescadores tienen un diestro saber sobre el entorno natural que habitan, que incluye las sorpresas e inclemencias que depara cada estación: el viento, los temporales, las posibilidades de pesca. A esto se suma un conocimiento práctico sobre las especies: las gaviotas refugiadas en los canales que anuncian viento; los grandes cardúmenes de corvina negra que resuenan 
como tambores en el puerto; la lisa que, con sus grandes ojos, puede ver la red y saltarla. Asimismo, los pescadores desafían las clasificaciones linneanas respecto de las especies icónicas de la Bahía Samborombón - la corvina negra y la corvina rubia - a las cuales bautizan con un amplio set de nombres. ${ }^{41}$ Según su tamaño o características morfológicas, los pescadores identifican a la corvina rubia como "roncadora", "perita" y "carbonera", y a la corvina negra (Pogonia cromis) como "mora" y "morita". ${ }^{42}$

A tono con el idioma imaginado por Borges (1974: 709), donde el nombre de cada ser "indica todos los pormenores de su destino, pasado y venidero", una taxonomía ad hoc es diseñada por los pescadores para las especies más cercanas a su experiencia.

\section{c) El saber provisto por la captura}

Aunque pueda resultar un anatema para los conservacionistas, lo cierto es que también se conoce a las especies cuando se las pesca o se las caza. Si los conservacionistas aspiran a crear reservas prístinas, libres de toda intervención humana, los pescadores no creen que exista una contradicción entre formar parte de un medio y explotarlo.

La antropología ya ha demostrado que, bajo la perspectiva de pequeñas comunidades de subsistencia como los grupos de cazadores y recolectores, no existe una incompatibilidad entre la conservación y la participación en un medio ambiente: la interacción con este último es, básicamente, no violenta (véase Ingold 2000: 68-71).

\section{EPÍLOGO:}

\section{LA ALTERNANCIA DE PARADIGMAS EN UNA COMUNIDAD DE TRABAJO}

Como expusimos en el artículo, la preocupación de los biólogos por disminuir la mortalidad de delfines y tortugas los llevó a convocar a algunos pescadores de San Clemente del Tuyú con el objeto de ensayar una tecnología de reducción de la captura incidental.

Visto como un todo, el corpus discursivo y de prácticas de los pescadores artesanales mixtura paradigmas que, desde una mirada distanciada, podrían considerarse excluyentes entre sí.

En primer lugar, hemos visto la adhesión a ciertos preceptos conservacionistas cuando las circunstancias así lo requieren en pos de su propio beneficio.

41 Con un espíritu similar, una bióloga y dos aborígenes qom - oriundos de las provincias argentinas de Chaco y Formosa - realizaron una notable sistematización etnozoológica sobre los animales qoms. Véase Medrano et al. (2011).

42 Esta nomenclatura es compartida con los compradores de pescado, que fijan el precio de las especies según sean utilizadas para harina o para consumo humano. 
En efecto, durante el proceso de incorporación del saber experto de los biólogos, algunos pescadores artesanales reconvierten esas especies frágiles en peligro de extinción en un recurso simbólico, adicionando nuevos pliegues a su representación de sí mismos como pescadores experimentados. Si bien este "conservacionismo estratégico" retoma elementos del conservacionismo canónico de los expertos, al mismo tiempo difiere en el rol atribuido a la agencia humana sobre la naturaleza.

En segundo lugar, ese conservacionismo estratégico - homologable al paternalismo descripto por Pálsson (2001) - convive con un "orientalismo a pequeña escala”, que se expresa tanto en el arte de pesca escogido como en la percepción antropocéntrica de los animales próximos a su experiencia. Si el pescado es visto como un recurso explotable, las tortugas y lo delfines pasan a ser - en forma análoga - un recurso difícilmente explotable desde un punto de vista económico.

La alternancia de ambos paradigmas - paternalista y orientalista - se expresa del siguiente modo. Hacia ciertos interlocutores profesionales, los pescadores orientan un discurso políticamente correcto de protección de las especies indefensas, aunque dejando traslucir que esas mismas especies también pueden ser apreciadas en tanto recursos en el marco de un contexto de explotación propicio para ello.

Por último, la convivencia de los dos paradigmas comentados - característicos de las sociedades occidentales - no opaca un asunto largamente comprobado en nuestra experiencia etnográfica: el "tácito comunalismo" que impregna el mundo del trabajo y de la vida de esta comunidad de pescadores artesanales, y que se expresa en el conocimiento de las especies a partir de su interacción con ellas; y la antropomorfización de lobos, delfines y tortugas. Pese a que los animales son categorizados en términos de su posibilidad o no de funcionar como un recurso, esto no impide que estos animales participen del mismo mundo de las personas. Dicho de otro modo, el discurso de la explotación no es excluyente de una práctica de cotidiana intimidad con diversas especies. No resulta aventurado definir entonces al universo de prácticas y discursos de los pescadores como un "continuum entre la reciprocidad y la explotación" (Brightman en Pálsson 2001: 96).

La yuxtaposición de los tres paradigmas aquí expuestos entraña, en principio, una contradicción: el orientalismo y el paternalismo nos remiten a una visión de la naturaleza como algo externo al mundo de los humanos, mientras que el comunalismo implica la cosmovisión inversa. No obstante, como señala Milton (1997: 10), las sociedades que tienen muchos modos de interactuar con el entorno tendrán también visiones múltiples y complejas sobre este.

En un mismo grupo humano pueden coexistir, pues, ambas visiones de la naturaleza - como algo externo o como parte del propio mundo - tal como intentamos demostrar para el caso de esta comunidad de pescadores. 
En sus interacciones, biólogos y pescadores artesanales negocian cuáles serán aquellos criterios técnicos y morales que mínimamente han de compartir en torno a la fragilidad de las especies. La conversión material y espiritual de los pescadores ha de forjarse una vez que se consolide el aprendizaje en torno a cuán frágil - o lo que es casi lo mismo, cuán relevante y única - ha de resultar cada una de las especies marinas que irrumpen en su práctica de pesca: tortugas, delfines, lobos marinos.

A juicio de los biólogos, resultaba imperativo instruir a los pescadores para que logren la cercanía moralmente exacta con esas frágiles especies. Lo que para unos puede ser una especie cuasi sagrada, valiosa, digna de la más sofisticada estrategia de protección, para otros puede ser un eventual recurso económico, un "algo" que puede ser intercambiado o a partir del cual se obtiene una retribución económica.

Lejos de contar con un camino único de decodificación, las premisas conservacionistas de los biólogos son retraducidas por los pescadores a partir de sus trayectorias vitales, así como de sus competencias culturales específicas. En efecto, al conocimiento sobre las especies y el medio ambiente adquirido mediante su práctica de pesca, los pescadores artesanales añaden conocimientos técnico-científicos producto de su interacción con los expertos de las ONG y organismos del Estado, constituyendo así un conocimiento heterogéneo e híbrido.

La atención sobre las perspectivas locales y los puntos de vista nativos acerca de la protección de especies amenazadas permite reflexionar sobre las actuales acciones de manejo en un área de interés tanto para la conservación de especies protegidas como para la explotación de recursos pesqueros. Creemos que las soluciones estrictamente biológicas a la captura incidental se verían significativamente enriquecidas al incorporar el mundo del trabajo y de la vida de los pescadores. Ese mundo contempla no solo las características socioeconómicas de la pesca artesanal en Argentina sino también la cosmovisión de esa comunidad: su relación entre pares, con las especies animales y con la bahía, así como los vínculos y negociaciones que ellos establecen con los conservacionistas y las demás flotas que explotan los recursos pesqueros. 


\section{BIBLIOGRAFÍA}

ÅRHEM, Kaj, 2001, “La red cósmica de la alimentación: la interconexión de humanos y naturaleza en el noroeste de la Amazona”, en Philippe Descola y Gísli Pálsson (orgs.), Naturaleza y Sociedad: Perspectivas Antropológicas. México, DF, Siglo XXI Editores, 214-236. BIRD-DAVID, Nurit, 1992, "Beyond 'The Hunting and Gathering Mode of Subsistence': culture-sensitive observations on the Nayaka and other modern hunter-gatherers", Man, n. s., 27 (1): 19-44.

BOLTANSKI, Luc, 1975, Los Usos Sociales del Cuerpo. Buenos Aires, Ediciones Periferia. BORDINO, Pablo, et al., 2006, "Esfuerzos para reducir la mortalidad incidental del delfín Franciscana (Pontoporia blainvillei) en Argentina”, ponencia presentada en las VI Jornadas Nacionales de Ciencias del Mar y XIV Coloquio de Oceanografía, Puerto Madryn.

BORGES, Jorge L., 1974, “El idioma analítico de John Wilkins”, en J. L. Borges, Otras Inquisiciones: Obras Completas. Buenos Aires, Emecé Editores, 706-709.

BOURDIEU, Pierre, 1986, "Notas provisionales sobre la percepción social del cuerpo", en Charles Wright Mills et al. (orgs.), Materiales de Sociología Crítica. Madrid, La Piqueta, 183-194.

BOURDIEU, Pierre, 1991, El Sentido Práctico. Madrid, Taurus.

BRAILOVSKY, Antonio E., y Dina FOGUELMAN, 2013, Memoria Verde: Historia Ecológica de la Argentina. Buenos Aires, Debolsillo (11. a edición).

CARMAN, María, 201 1, Las Trampas de la Naturaleza: Medio Ambiente y Segregación en Buenos Aires. Buenos Aires, Fondo de Cultura Económica/CLACSO.

CAROZZA, Claudia, et al., 2004, "Corvina rubia (Micropogonias furnieri)”, en Ramiro Sánchez y Susana I. Bezzi (orgs.), El Mar Argentino y Sus Recursos Pesqueros: Los Peces Marinos de Interés Pesquero. Caracterización Biológica y Evaluación del Estado de Explotación, tomo 3. Mar del Plata, Publicaciones Especiales INIDEP, 255-270.

CITRO, Silvia, 2010, Cuerpos Plurales: Antropología de y desde los Cuerpos. Buenos Aires, Editorial Biblos.

Cousseau, María B., y Ricardo G. PerrotTA, 1998, Peces Marinos de Argentina: Biología, Distribución, Pesca. Mar del Plata, Publicaciones Especiales INIDEP.

DESCOLA, Philippe, 2005 [2001], "Más allá de la naturaleza y la cultura”, Etnografías Contemporáneas, 1 (1): 93-114.

ELÍAS, Inés, et al., 201 1, "Coastal fisheries of Argentina”, en Silvia Salas, Ratana Chuenpagdee, Anthony Charles y Juan Carlos Seijo (orgs.), Coastal Fisheries of Latin America and the Caribbean. Roma, Food and Agriculture Organization of the United Nations (FAO Fisheries and Aquaculture Technical Papers, vol. 544), 13-48.

ERRAZTI, Elizabeth, et al., 2009, "Sistema pesquero artesanal de la Provincia de Buenos Aires”, ponencia presentada en XIII Congreso Latinoamericano de Ciencias del Mar y VIII Congreso de Ciencias del Mar, La Habana.

FAO, 2005, "Guía del administrador pesquero: Medidas de ordenación y su aplicación".

Roma, Organización de las Naciones Unidas para la Agricultura y la Alimentación (Documento Técnico de Pesca 424), disponible en < http://www.fao.org/docrep/008/y3 427s/y3427s00.htm > (última consulta en mayo 2016).

GROOM, Martha J., et al., 2006, Principles of Conservation Biology. Sunderland, Sinauer Associates (3. ${ }^{\mathrm{a}}$ edición).

HALL, Martin A., 1996, "On bycatches", Reviews in Fish Biology and Fisheries, 6: 319-352. 
HVIDING, Edvard, 2001, "Naturaleza, cultura, magia, ciencia: sobre los metalenguajes de comparación en la ecología cultural”, en Philippe Descola y Gísli Pálsson (orgs.), Naturaleza y Sociedad: Perspectivas Antropológicas. México, DF, Siglo XXI Editores, 192-213.

INGOLD, Tim, 2000, The Perception of the Environment: Essays on Livelihood, Dwelling and Skill. Londres, Psychology Press.

LASTA, Carlos A., et al., 2001, "Flota costera argentina: antecedentes y situación actual", en María I. Bertolotti, Guillermo A. Verazay y Ruth Akselman (orgs.), El Mar Argentino y Sus Recursos Pesqueros: Evolución de la Flota Pesquera, Artes de Pesca y Dispositivos Selectivos, tomo 3. Mar del Plata, Publicaciones Especiales INIDEP, 89-106.

LATOUR, Bruno, et al., 1991, "Crises des environnements, défis aux sciences humaines", Futur Antérieur, 6: 28-56.

LITTLE, Paul E., 1999, "Environments and environmentalisms in anthropological research: facing a new millennium”, Annual Review of Anthropology, 28: 253-284.

MATEO, José, 2003, De Espaldas al Mar: La Pesca y los Pescadores en Argentina (Siglos XIX y XX). Barcelona, Universitat Pompeu Fabra, disertación de doctorado.

MEDrANO, Celeste, et al., 2011, Zoología Qom: Conocimientos Tobas sobre el Mundo Animal. Santa Fe, Ediciones Biológica.

MILTON, Kay, 1997, "Ecologies: anthropology, culture and the environment", International Social Science Journal, 49: 477-495.

NYGREN, Anja, 1999, "Local knowledge in the environment-development discourse: from dichotomies to situated knowledges”, Critique of Anthropology, 19: 267-288.

PÁLSSON, Gísli, 2001, "Relaciones humano-ambientales: orientalismo, paternalismo y comunalismo”, en Philippe Descola y Gísli Pálsson (orgs.), Naturaleza y Sociedad: Perspectivas Antropológicas. México, DF, Siglo XXI Editores, 80-100.

RIVAL, Laura, 2001, "Cerbatanas y lanzas: la significación social de las elecciones tecnológicas de los Huaorani”, en Philippe Descola y Gísli Pálsson (orgs.), Naturaleza y Sociedad: Perspectivas Antropológicas. México, DF, Siglo XXI Editores, 169-191.

SANTOS, Boaventura de Sousa, 2001, "El fin de los descubrimientos imperiales", Chiapas, 11: 17-27. 